Original Paper

\title{
Characterization in Chemical Composition of the Oil Palm (Elaeis guineensis)
}

\author{
Masashi Shibata, Mahendora Varman, Yosuke Tono, Hisashi MiYafuji, and Shiro SaKa \\ (Received March 12, 2007)
}

\author{
アブラヤシの化学成分組成分析 \\ 芝田正志，バーマン マヘンドラ，東野陽介，宮藤久士，坂 志朗
}

\begin{abstract}
As the worldwide production of palm oil is increasing, concomitant wastes of unutilized parts of the oil palm is also increasing. Thus, effective utilization of these wastes is expected. In this paper, therefore, the chemical composition of cellulose, hemicellulose, lignin and other minor cell wall components was studied for six different parts of the oil palm such as trunk, frond, mesocarp, shell, kernel cake and empty fruit bunch (EFB). As a result, it was shown that cellulose is in a range between $20-40 \mathrm{wt} \%$ with hemicellulose being 10 $35 \mathrm{wt} \%$, whereas lignin in a range between $23-52 \mathrm{wt} \%$. More in detail, the shell contained the highest lignin about $52 \mathrm{wt} \%$ but the kernel cake no lignin, while the rest in a range between $23-35 \mathrm{wt} \%$, being composed of guaiacyl and syringyl moieties without p-hydroxyphenyl residue. This is very similar to the hardwood-type lignin, rather than softwood-type lignin. On hemicellulose, mannan was rich in kernel cake, while glucuronoxylan rich in the other parts, with 1.8-8.5 xylose units per one uronic acid.

These lines of information are useful for the efficient utilization of the whole parts of the oil palm which is necessary for the sustainable development of the biomass resources.
\end{abstract}

\section{Key Words}

Oil palm, Trunk, Frond, Mesocarp, Endocarp (Shell), Kernel cake, EFB, Chemical composition, Cellulose,

Hemicellulose, Lignin, Extractives, Ash, Neutral sugar, Uronic acid

\author{
1. 緒 言 \\ アブラヤシは, マレーシアやインドネシアをはじめ東南ア \\ ジアで広く栽培され，パーム油やパーム核油の採取に用いら \\ れている。パーム油の生産量は 1995 年からの 10 年間で倍増 \\ し，2004 年には年間 3,000 万 $\mathrm{t} に$ 達し，世界総油脂生産量の \\ 23\%にも及んでいる11。しかし，このパーム油を製造する過程 \\ で, 大量の副産物が排出され，それらの有効利用が望まれて \\ いる ${ }^{2)}$ 。 \\ たとえば，アブラヤシは $25 \sim 30$ 年で植え替えられるため,
} 植え替え時の廃棄物としてマレーシアにおいては年間 500 万 tの幹 (Trunk)と 110 万tの茎葉 (Frond) が産出している ${ }^{3)}{ }^{4)}$ 。 また，工場におけるパーム油，パーム核油の生産工程で，年 間 700 万 t の中果皮 (Mesocarp), 410 万 t の果実殼（Shell）, 190 万七パーム核粕 (Kernel Cake), 1,340万tの空果房 (EFB: Empty Fruit Bunch) が産出している5)。

Graduate School of Energy Science, Kyoto University

Yoshida-honmachi, Sakyo-ku, Kyoto 606-8501, Japan
これら副産物は，飼料やパーム油製造工場でのボイラーの 燃料として利用されているが, 物理的, 化学的特性を生かし た有効利用が充分になされていないのが現状である。した がって，その有効利用を推し進めていくことが，バイオマス 資源の総体利用の観点から，また環境問題の改善の観点から 重要である。

さて，バイオマス資源の有効利用を進めていく上で重要な ことは，バイオマスの植物分類上の位置付けとその化学的，物 理的，さらには物理化学的特性との関連を明らかにしておく ことである。アブラヤシは植物分類学上，被子植物の単子葉 類に分類され，同じ被子植物の双子葉類に属する広葉樹とは 異なる。さらには，裸子植物の針葉樹類とは大きく異なる6)。 そこで, 本研究ではバイオマス資源の大半を占める針葉樹 や広葉樹とは異なる，アブラヤシの化学成分組成分析，特に ヘミセルロースの構成糖及びリグニンの構成核に関する分析

京都大学大学院エネルギー科学研究科

于 606-8501 京都市左京区吉田本町 
を行うことにした。また針葉樹や広葉樹での知見と比較しな がら, 今後のアブラヤシの総体利用のための単子葉植物アブ ラヤシの基礎的知見を得ることにした。

\section{2. 実 験}

\section{1 試 料}

試料として，マレーシア産アブラヤシ（Elaeis guineensis Jacq.) を用い, Fig. 1 に示す幹 (Trunk), 菱葉 (Frond), 中 果皮 (Mesocarp), 内果皮 (Endocarp) (本研究では，以降Shell (果実殼) と表記する)，核（Kernel）（本研究では，Kernel か らパーム核油を搾り出した残渣を対象とするため, 以降 Kernel Cake (パーム核粕) と表記する) および空果房 (EFB:Empty Fruit Bunch)に当たる 6 部位を取り出した。これらの試料を, 別々にウィレー型粉砕機（1029-C，吉田製作所製）を用いて $\phi 0.5 \mathrm{~mm}$ 以下に粉砕後, エタノール :ベンゼン $(1: 2(\mathrm{v} / \mathrm{v}))$ (共に，ナカライテスク製，特級)を用いて 8 時間のソックス レー抽出を行い，実験に供した。

\section{2 化学成分組成分析}

2.1での抽出済試料に対し，定法7)に従い，ホロセルロース， $\alpha$-セルロース, クラーソンリグニン，酸可溶性リグニンおよ び扊分について, それらの化学成分分析を行った。分析手順 を Fig. 2 に示す。

\section{3 ヘミセルロースの構成糖分析}

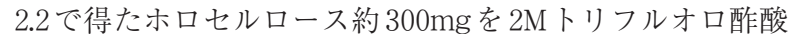
(TFA，ナカライテスク製，特級) $30 \mathrm{ml}$ に加え，オートクレー ブにて $120^{\circ} \mathrm{C} ， 1$ 時間加熱処理した。その後試料中の TFA を
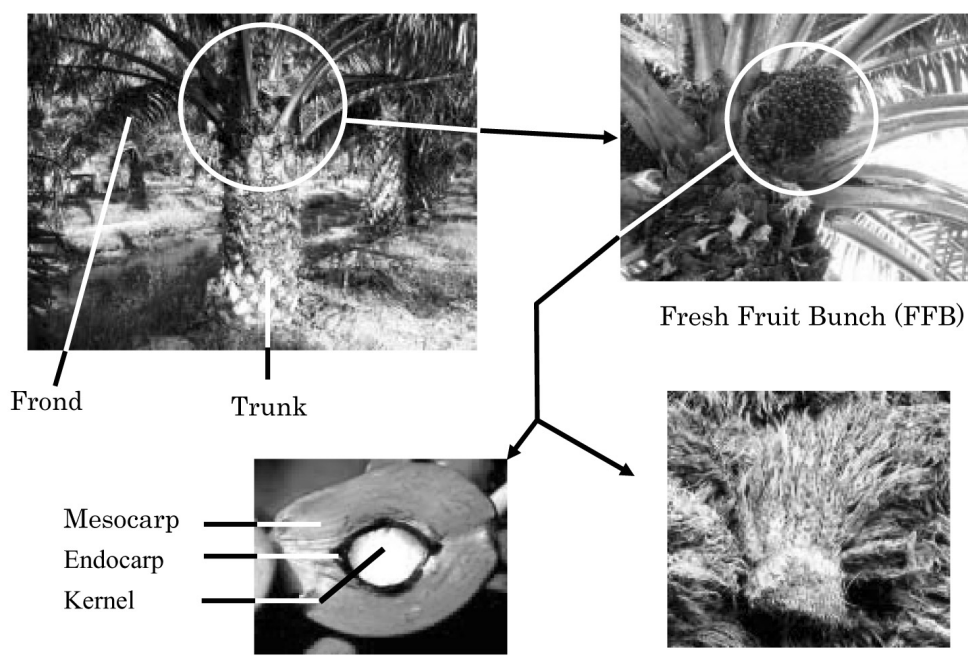

Fruit

Empty Fruit Bunch (EFB)

Fig. 1 Various parts of the oil palm²)

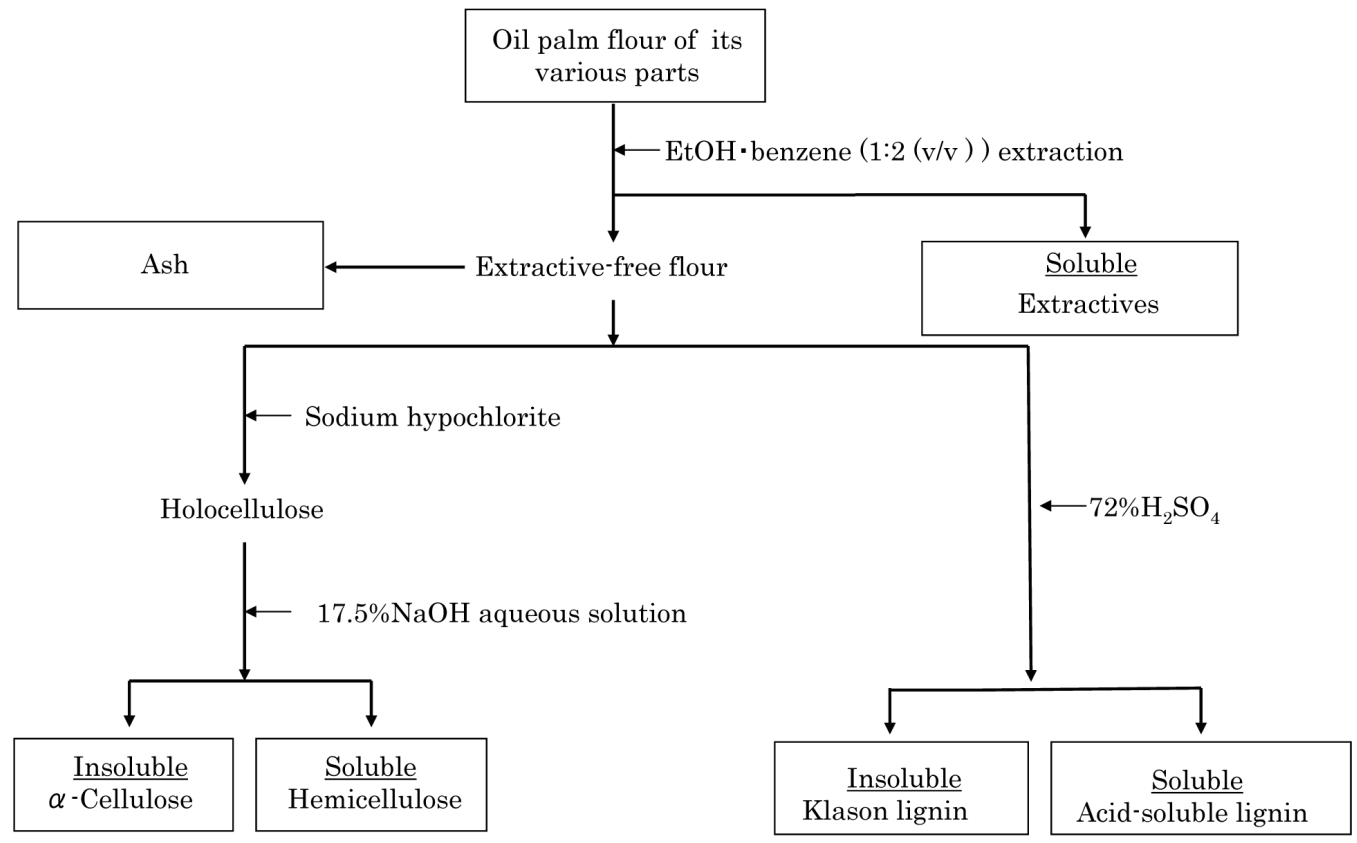

Fig. 2 A flowchart of the oil palm for the chemical composition analysis of its various parts 
蒸発乾固させ，残渣を水 $20 \mathrm{ml}$ に溶解させた後に水可溶部と水 不溶残渣に濾別した。水可溶部に対してはイオンクロマトグ ラフィー（ダイオネクス ICS-3000）により，以下の条件で中 性糖の分析を行った（カラム：CarboPac PA10，カラム温度： $35^{\circ} \mathrm{C}$ ，キャリア： $\mathrm{H}_{2} \mathrm{O} ，$ 流速 $: 1.0 \mathrm{ml} /$ 分)。

また，2.1での抽出済試料 $50 \mathrm{mg}$ を用いて，定法 ${ }^{8)}$ に従いウ ロン酸の定量を行った。

\section{4 クラーソンリグニンのリグニン構成核分析}

定法 ${ }^{9)}$ に従って，2.1での抽出済試料 $10 \mathrm{mg}$ に対し，アルカ リ性ニトロベンゼン酸化を行い，得られたサンプルをガスク ロマトグラフ (GC) 分析装置 (Shimadzu GC-18A) を用いて, 以下の条件で GC 分析した。カラム : Shimadzu CBP5 $25 \mathrm{~m} \times$ $0.25 \mathrm{~mm} \phi$, 試料気化室: $250^{\circ} \mathrm{C}$, 検出器: FID $; 250^{\circ} \mathrm{C}$, カラム 温度: $100^{\circ} \mathrm{C}$ ( 1 分間保持), $100^{\circ} \mathrm{C} \rightarrow 270^{\circ} \mathrm{C}\left(10^{\circ} \mathrm{C} /\right.$ 分), 270 ${ }^{\circ} \mathrm{C}$ (10 分間保持), キャリアガス: He, 流速 : $1.5 \mathrm{ml} /$ 分。

\section{5 フーリエ変換赤外吸収スペクトル $(F T-I R)$ 分析}

2.2 で得た絶乾状態のクラーソンリグニン $2 \mathrm{mg}$ を $200 \mathrm{mg}$ の 絶乾 $\mathrm{KBr}$ と混合して錠剤とし，フーリエ変換赤外分光光度計 (Shimadzu，FT-IR8000）を用いてFT-IR 分析を行った。

\section{3. 結果及び考察}

\section{1 化学成分分析}

Table 1に，化学成分分析により得られたアブラヤシ 6 部位 (Trunk, Frond, Mesocarp, Shell, Kernel Cake およびEFB) でのセルロース，ヘミセルロース，リグニン，抽出成分拉よ び灰分の含有率を示す。ここでShellはFig. 1におけるEndocarp であり，果実内部に存在する種子の外側を覆っている硬い殼 状物質である。一方, Kernel Cakeとは種子内部に存在する物 質であり，パーム核 (Kernel) からパーム核油を取り除いた残 渣である。

この成分分析結果より，セルロースの含有率は Shell で 20.5wt\% と低いが，その他の部位では30～40wt\%の範囲にあ ることがわかる。一方，へミセルロースについては，Mesocarp
で $9.8 w t \%$ と低いが，その他の部位では $22 \sim 35 w t \% の$ 值を示 している。リグニンは, 総リグニン＝クラーソンリグニン+ 酸可溶性リグニンで求まるが，部位により含有率が大きく異 なり，Shell が最大で $51.5 \mathrm{wt} \%(=49.9 \mathrm{wt} \%+1.6 \mathrm{wt} \%)$ を占め ている。

クラーソンリグニンとは $72 \%$ 硫酸に不溶のもので，それを リグニンとみなしている。日本のような温暖地域の樹木につ いては，ポリフェノール類のような，濃硫酸の処理で縮合し て不溶化するものがほとんどないため, クラーソンリグニン は，ほぼリグニンそのものを示すといえる。しかし熱帯材に は，上述のリグニン以外にも濃硫酸により縮合し不溶化する 成分があるため，クラーソンリグニン量からリグニン量その ものを推定することはできない場合がある ${ }^{10) 。 ~}$

酸可溶リグニンについては，わが国における針葉樹材で0.1$0.3 \mathrm{wt} \%$ 程度，広葉樹材では $2-4 \mathrm{wt} \%$ でる ${ }^{11}$ 。一方アブラ ヤシでは Table 1 に示すように，最大 $3.8 w t \%$ と広葉樹と同様 の大きな值を示している。これはアブラヤシのリグニンが，広 葉樹と同様，シリンギル核などからなる非縮合型リグニンを 多く含有することを示唆している。

次に抽出成分について, MesocarpおよびKernel Cakeでは, その含有率が他の部位に比べて高い值を示している。これは, Mesocarp と Kernel Cakeがそれぞれパーム油（Palm Oil）およ びパーム核油 (Palm Kernel Oil) の搾油後に得られる廃棄部位 であるため，残留油分が含まれるためであると考えられる。こ こでは搾取した油については化学成分組成の対象としていな い。

灰分については，わが国における針葉樹材，広葉樹材共に 0.3-0.6wt\% 程度 ${ }^{12)}$ であることと比べると，その值は格段に大 きいことがわかる。しかし，このような事例は熱帯広葉樹材 では多く見られ，アブラヤシも熱帯広葉樹材に近い含量を示 すものと考えられる。

これらアブラヤシの各部位に対し，いくつかの化学成分分 析結果が報告されている。たとえば，Mae ${ }^{13)} ら は ，$ Shellのセ ルロース，へミセルロース，リグニンの割合をそれぞれ 31 , 20, $49 \mathrm{wt} \%$ としており, 本研究と同様, リグニン含有率が高

Table 1 Chemical composition of various parts of the oil palm (wt\%)

\begin{tabular}{lcccccc}
\hline \multirow{2}{*}{ Part } & \multirow{2}{*}{ Cellulose $^{* 1}$} & \multirow{2}{*}{ Hemicellulose*2 $^{* 2}$} & \multicolumn{2}{c}{ Lignin } & \multirow{2}{*}{ Extractives $^{* 3}$} & \multirow{2}{*}{ Ash } \\
\cline { 4 - 5 } Trunk & 30.6 & 33.2 & 24.7 & 3.8 & 3.6 & 4.1 \\
Frond & 39.5 & 29.8 & 21.2 & 2.1 & 1.7 & 5.7 \\
Mesocarp & 39.5 & 9.8 & 32.8 & 0.1 & 8.6 & 9.3 \\
Shell & 20.5 & 22.3 & 49.9 & 1.6 & 4.7 & 1.0 \\
Kernel Cake & 35.7 & 30.3 & $15.6^{* 4}$ & $0.1{ }^{* 4}$ & 11.7 & 6.7 \\
EFB & 37.9 & 35.0 & 22.9 & 1.1 & 2.7 & 1.5 \\
\hline
\end{tabular}

$* 1 \quad$ Cellulose $=\alpha$-Cellulose,

$* 2$ Hemicellulose $=$ Holocellulose $-\alpha$-Cellulose,

*3 Ethanol : Benzene $=1: 2(\mathrm{v} / \mathrm{v})$

*4 Although these values could be obtained by the method with $72 \% \mathrm{H}_{2} \mathrm{SO}_{4}$, they do not represent true lignin content as described later 
いことを報告している。Wan Rosli14) らは，Frondの成分とし てホロセルロース $86.5 \mathrm{wt} \% ， \alpha$-セルロース $62.3 \mathrm{wt} \%$ ，(両者

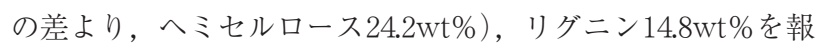
告しており, 本研究よりも $\alpha$-セルロースの割合が高い。Sun ${ }^{15)}$ らは, Trunk に対してセルロース 41.4wt\%, ヘミセルロース 34.4wt\%，リグニン $16.5 \mathrm{wt} \%$ および扊分 $3.4 \mathrm{wt} \%$ ， EFBに対し てそれぞれ 44.4，30.9，14.2wt\%および 2.8wt\% と報告してお り, 本研究での数值とおおよそ一致している。

\section{2 ヘミセルロースの構成糖分析}

Table 2に，アブラヤシの 6 部位における，ヘミセルロース を構成する中性糖および酸性糖としてのウロン酸の割合を示 す。ただし，へミセルロースを構成する中性糖とウロン酸の 全量をへミセルロースと考え，それぞれの糖成分を重量％で 示している。これより，へミセルロースは，主にキシロース から構成されており，例外的にKernel Cakeはマンノースが主 要構成糖であることがわかる。また，Trunk及びFrondは，ア ラビノースの割合が他の部位よりも高いが，その絶対量は低 く, Trunk 及び Frond でそれぞれ 2.7wt\%，1.5wt\%である以 外は $1 \mathrm{wt} \%$ 以下である。

さらに，ウロン酸はキシロースの含有率が高いほど高いこ とがわかる。Timell らは，針葉樹のモミ(Abies amabilis) キ シランを構成するキシロース 6 個に対して 1 個のウロン酸を 含んでいると報告している ${ }^{16)}$ 。広葉樹でのシラカバ (Betula papyrifera) キシラン 17) では 10 個のキシロースに対しウロン 酸 1 個の構成比であると報告している。アブラヤシでは, キ シロース $1.8 \sim 8.5$ 個，平均 6 個に対しウロン酸側鎖の割合が 1 個と針葉樹並みに高くなっているのが特徵である。

Akmarら ${ }^{18)}$ は，アブラヤシのTrunkおよびEFBを，水，熱 水拉よび $2 \mathrm{~mol} / \mathrm{l} \mathrm{TFA} て ゙$ 処理し, その残渣をTFAでさらに処 理して得られた溶液を GC 分析した結果, それぞれの溶解液 から，アラビノース，ガラクトース，グルコース，マンノー ス，キシロースなどの糖が検出された。また定量分析の結果， グルコースが最も多く，次いでキシロースが多量に存在する ことを明らかにしている。グルコースは, 主にセルロース由 来と考えられることから, Trunk や EFBのへミセルロースの 主な構成糖はキシロースであることが示されている。Wan
Rosli ら ${ }^{19)}$ は，アブラヤシの Frond の構成糖について，グル コース $66.6 \mathrm{wt} \%$ ，キシロース $28.9 \mathrm{wt} \%$ ，マンノース $2.2 \mathrm{wt} \%$, アラビノース $1.5 \mathrm{wt} \%$ ，ガラクトース $0.9 \mathrm{wt} \%$ を報告しており， キシロースが多く含まれていることを明らかにしている。こ の結果は本研究結果とも一致している。Daudら ${ }^{20)}$ は, ${ }^{13} \mathrm{C} \mathrm{NMR}$ を用いてKernel Cakeの糖の分析を行い，へミセルロースの主 要成分がガラクトマンナンであるとしている。本研究でも， Kernel Cakeのへミセルロースはマンノースが84.8wt\%，ガラ クトースが $4.8 \mathrm{wt} \%$ と Daud らの結果に近い值が得られてい る。

以上の結果から, Kernel Cake以外の 5 つの部位でのへミセ ルロースはウロン酸残基を比較的多く含むグルクロノキシラ ンであると推定される。Table 2に示すように，アブラヤシ各 部位の構成糖が明らかとなり, それらの特徵を生かした有効 利用への展開が考えられる。たとえば，キシロースが多い部 分ではキシロースの人工甘味料であるキシリトールへの変換 が期待でき，マンノースの多いKernel Cakeはエタノール発酵 の基質などとして利用が期待できる。

\section{3 リグニン構成核分析}

Table 3に，アルカリ性ニトロベンゼン酸化により求めたア ブラヤシの 6 部位におけるリグニンのグアイアシル $(\mathrm{G})$ 核, シリンギル $(\mathrm{S})$ 核および $p$-ヒドロキシフェニル $(\mathrm{P})$ 核の構 成モル比を示す。

アルカリ性ニトロベンゼン酸化では, G核，S核およびP核

Table 3 Molar ratio of syringyl and p-hydroxyphenyl residues to guaiacyl residue in the lignin of the various parts of the oil palm

\begin{tabular}{lcc}
\hline Part & Lignin $(\mathrm{wt} \%)$ & $\mathrm{G}: \mathrm{S}: \mathrm{P}(\mathrm{mol} / \mathrm{mol})$ \\
\hline Trunk & 28.5 & $1.0: 3.5: 0.0$ \\
Frond & 23.3 & $1.0: 1.4: 0.0$ \\
Mesocarp & 32.9 & $1.0: 1.2: 0.0$ \\
Shell & 51.5 & $1.0: 0.7: 0.0$ \\
Kernel Cake & 0 & n.d. \\
EFB & 23.0 & $1.0: 2.8: 0.0$ \\
\hline
\end{tabular}

G: Guaiacyl unit, S: Syringyl unit, P: p-Hydroxyphenyl unit, n.d.: not detected

Table 2 Hemicellulose and its neutral sugars and uronic acid of various parts of the oil palm

\begin{tabular}{lcrrrrrrr}
\hline \multirow{2}{*}{ Part } & $\begin{array}{c}\text { Hemicellulose*1 } \\
(\text { wt\%) }\end{array}$ & \multicolumn{6}{c}{ Sugars and uronic acid in hemicellulose (wt\%) } & Xyl/UA \\
\cline { 3 - 7 } & & Ara & Xyl & Man & Glc & Gal & UA & (molar ratio) \\
\hline Trunk & 33.2 & 8.2 & 55.7 & 1.2 & 18.8 & 4.9 & 11.3 & 6.3 \\
Frond & 29.8 & 4.9 & 52.0 & 6.3 & 20.5 & 4.8 & 11.6 & 6.1 \\
Mesocarp & 9.8 & 1.7 & 48.9 & 5.8 & 23.2 & 4.0 & 16.5 & 3.8 \\
Shell & 22.3 & 0.6 & 63.4 & n.d. & 21.8 & 2.3 & 13.7 & 6.0 \\
Kernel Cake & 30.3 & 0.9 & 4.3 & 82.4 & 4.0 & 4.8 & 3.1 & 1.8 \\
EFB & 35.0 & 1.5 & 63.0 & n.d. & 23.1 & 2.7 & 9.6 & 8.5 \\
\hline
\end{tabular}

${ }^{* 1}$ Based on the original wood, ${ }^{* 2}$ Based on hemicellulose Ara: Arabinose, Xyl: Xylose, Man: Mannose, Glc: Glucose, Gal: Galactose, UA: Uronic acid n.d.: not detected 
リグニンより，それぞれバニリン，シリンガアルデヒドおよ びp-ヒドロキシフェニルアルデヒドを与える ${ }^{21)}$ これによっ て，リグニンを構成する核の種類を明らかにすることが可能 となる。得られた結果はTable 3の通りであるが, 各部位のリ グニンに対しバニリンやシリンガアルデヒドを与えたもののp ーヒドロキシフェニルアルデヒドはほとんど確認されなかった。 このことより，各部位には $\mathrm{G}$ 核および多量の $\mathrm{S}$ 核りグニンが 存在することが明らかになった。しかし Kernel Cakeからは, バニリン，シリンガアルデヒド， $p$-ヒドロキシフェニルアル デヒドのいずれもが検出されなかったことから, Kernel Cake にはリグニンはほとんど存在しないものと推察される。した がってKernel Cakeのクラーソンリグニン量は $15.6 \mathrm{wt} \%$ である が，他の 5 部位とは異なり，これはリグニン以外の硫酸不溶 性物質であると考えられる。したがって, Table 3でのKernel cakeのリグニン量は 0 wt\%とした。

Run-Cangら 22) はアルカリニトロベンゼン酸化を用いてEFB およびTrunkのリグニンを処理した結果, 主要酸化物がシリ ンガアルデヒド，バニリンの順に多く得られ，これらのリグ ニンの主要構成核は $\mathrm{S}$ 核及び $\mathrm{G}$ 核であると報告している。こ れは本実験の結果と一致している。

\section{4 フーリエ変換赤外吸収スペクトル $(\mathrm{FT}-\mathrm{IR})$ 分析}

Fig. 3に, アブラヤシの 6 部位から得られたクラーソンリグ ニンの波数 $1270 \mathrm{~cm}^{-1}$ 近辺での FT-IR スペクトルを示す。波 数 $1270 \mathrm{~cm}^{-1}$ ではリグニンのメトキシ基に起因する吸収が存 在するが, このFT-IRスペクトルょりTrunk, Frond, Mesocarp, Shell およびEFBではその吸収が確認できるのに対し, Kernel Cakeでは同波数での吸収がほとんど確認できない。したがっ て Trunk, Frond, Mesocarp, Shell およびEFBの 5 部位には リグニンが存在するものの, 上述の通り, Kernel Cakeではほ とんどリグニンが存在しないことが示唆される。

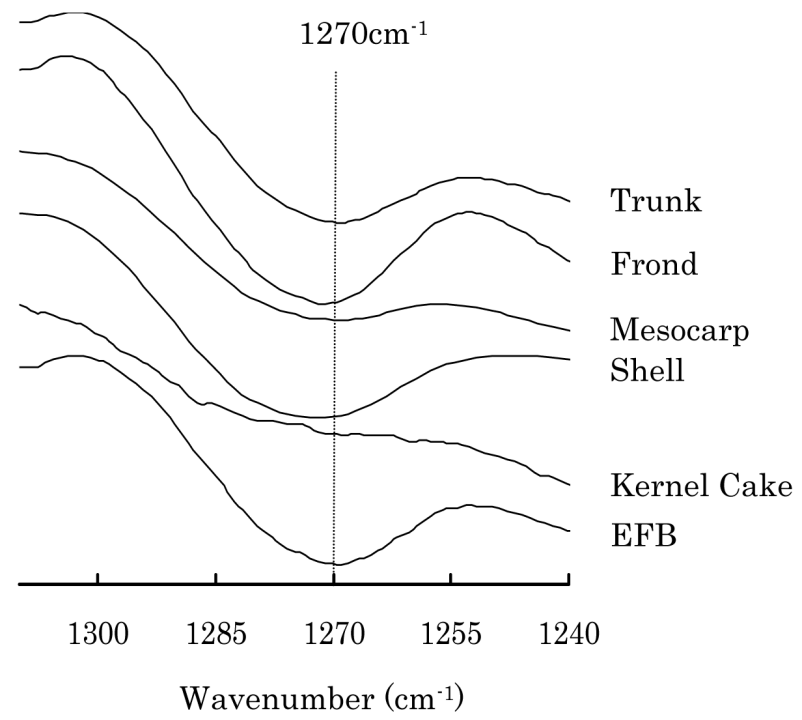

Fig. 3 FT-IR spectra of the lignin in the various parts of the oil palm

\section{4. 結 言}

本研究では，アブラヤシ未利用部の有効利用を目的として， 幹 (Trunk), 茎葉 (Frond), 中果皮 (Mesocarp), 内果皮 (Endocarp) の果実殼（Shell），パーム核粕（Kernel Cake）お よび空果房 (EFB) の計 6 部位の化学成分組成の分析，特にへ ミセルロースの構成糖の分析およびリグニンの構成核の分析 を行った。その結果，以下の 3 点が明らかになった。

1.リグニンはKernel Cakeには存在せずShellに最も多く含ま れ，その構成は $\mathrm{G}$ 核および $\mathrm{S}$ 核からなっており，P核をほ とんど含まない。このリグニンは針葉樹よりもむしろ広葉 樹型リグニンに類似の構造を示すものである。

2. ヘミセルロースは, Kernel Cakeに扔いてマンノースを主構 成糖とするマンナンであり，それ以外の 5 部位ではキシ ロースを主構成糖とするグルクロノキシランからなり，お よそウロン酸残基 1 個に対しキシロースを3.5-8.5個有して いる。

3. Trunk は細胞密度が不均一であり, かつセルロースの含量 が低い23) ため，構造材料としての利用には不向きである。 以上の結果は， 6 部位に関する重要な基礎的知見であり, 現 在有効利用されずに廃棄されている部位を有効に活用し，ア ブラヤシの総合利用を可能にする上で有益である。持続可能 なバイオマス資源の利活用を可能にするためにもこれらの知 見が活用されることが望まれる。

\section{謝 辞}

本研究で用いた試料は，マレーシア工科大学の Farid Nasir Bin Hj Ani 教授, マレーシア科学大学の Abdul Rahman Mohamed 教授および Ir Mohd Omar Ab Kadir 教授より供与い ただいたものであり，ここに御礼申し上げる。

\section{文 献：References}

1) "Malaysian Oil Palm Statics," Malaysian Palm Oil Board, Selangor, Malaysia, 1-145(2005)

2）坂志朗，バイオディーゼルのすべて，（アイピーシー出 版), 坂志朗編著, p.4(2006): Saka, S., All about Biodiesel, (IPC Publisher), ed. by Saka, S., p. 4(2006)

3) Lim, K. O., Ahmaddin, F. H., Vizhi, S. M, Biores. Technol., 59, $33(1997)$

4) Lim, K. O., Renewable Energy Review Journal, 8, 55(1986)

5) Pusat Tenega Malaysia, Malaysia biomass-based power generation and cogeneration in the palm oil industry, (phase1), http://www.ptm.org.my/

6）岩㭇邦夫，馬渡峻輔，植物の多様性と系統，(裳華房), p.267-274(1998): Iwatsuki, K., Mawatari, S., Syokubutsu no Tayousei to Keitou,(Syoukabou), p. 267-274(1998)

7）黑田健一，木質科学実験マニュアル，(文永堂出版), p.92 (2000): Kuroda, K., Mokushitsu Kagaku Jikken Manual, (Buneido), p. 92(2000)

8）日本木材学会編, 木材科学実験書 II. 化学編, （中外産業調 査会), p.164-165(1990): Nihon Mokuzai Gakkai, Mokuzai 
Kagaku Jikken Syo II, Kagakuhenn, (Tyugaisangyou Tyousakai), p.164-165(1990)

9）日本木材学会編，木材科学実験書 II. 化学編，（中外産業調 查会), p.200-201(1990): Nihon Mokuzai Gakkai, Mokuzai Kagaku Jikken Syo II, Kagakuhenn, (Tyugaisangyou Tyousakai), p. 200-201(1990)

10）日本木材学会編，木材科学実験書 II. 化学編，（中外産業調 查会), p.156(1990): Nihon Mokuzai Gakkai, Mokuzai Kagaku Jikken Syo II, Kagakuhenn, (Tyugaisangyou Cyousakai), p. 156(1990)

11）坂井克己，木材の化学，(文永堂出版), p.126(1993): Sakai, K., Mokuzai no Kagaku, (Buneidou), p. 126(1993)

12）原口隆英，木材の化学，(文永堂出版), p.4 (1993): Haraguchi, T., Mokuzai no Kagaku, (Buneidou), p. 4(1993)

13) Mae, K., Hasegawa, I., Sakai, N., Miura, K., Energy Fuels, 14, $1212(2000)$

14) Wan Rosli, W. D., Law, K. N., Zainuddin, Z., Asro, R., Biores. Technol., 93, 233(2004)
15) Sun, R. C., Fang, J. M., Mott, L., Bolton, J., Holzforschung, 53, 253(1999)

16) Timell, T. E., Svensk Papperstidn., 64, 748(1961)

17) Marchessault, R. H., Liang, C. Y., J. Polym. Sci., 59, 357 (1962)

18) Akmar, P. F., Kennedy, J. F., Wood Sci.Technol., 35, 467 (2001)

19) Wan Rosli, W. D., Zainuddin, Z., Law, K. N., Asro, R., Ind.Crops Products, 25, 89(2007)

20) Daud, M. J., Jarvis, M. C., Phytochem., 31, 463(1992)

21）諸星紀幸，木材の化学， (文永堂出版), p.131 (1993): Moroboshi, N., Mokuzai no Kagaku, (Buneidou), p. 131 (1993)

22) Sun, R. C., Fang, J. M., Tomokinson, J., Bolton, J., Agric. Food Chem., 47, 2930 (1999)

23）野㴊正，バイオマス・エネルギー・環境，（アイピーシー出 版), 坂志朗編著, p.118(2001) : Nobuchi, T., biomass• Energy $•$ Environment, (IPC Publisher), ed. by Saka, S., p.118 (2001) 